DOI: https://doi.org/10.32838/2523-4803/70-3-16

УДК 322.334:658.5:633.1

\title{
Скиба М.В.
}

кандидат наук з державного управління, доцент,

Київський національний торговельно-економічний університет

\section{Skyba Maryna}

Kyiv National University of Trade and Economics

\section{УПРАВЛІННЯ ЗЕМЕЛЬНИМИ РЕСУРСАМИ: ДОСВІД КРАЇН ЄВРОПЕЙСЬКОГО СОЮЗУ}

\begin{abstract}
У статті розглянуто основні аспекти управління земельними ресурсами. На основі аналізу наукових джерел з'ясовано роль та значення землі для сталого економічного розвитку. 3'ясовано, що основними недоліками механізму реєстрації майна в Україні є надмірна складність процедури реєстрації власності; надмірні витрати часу та грошей під час реєстрації власності; низька якість системи управління земельними ресурсами порівняно з краӥнами СС. Визначено основні завдання держави у сфері управління земельними ресурсами, представлено досвід щуодо формування елементів системи управління земельними ресурсами в Свропі та запропоновано рекомендації. Зокрема, необхідними $\epsilon$ вдосконалення механізму реєстрації власності, створення ефективної, прозорої, відкритої та гнучкої структури державного управління з використанням сучасних інформаційних та комунікаційних технологій, здатних створювати та здійснювати узгоджену державну політику управління земельними ресурсами.
\end{abstract}

Ключові слова: земля, управління, Свропейський Союз, земельні ресурси, економічний розвиток.

Постановка проблеми. Основним національним багатством нашої держави є земля з їі родючими грунтами, рівень якості яких є одним з найвищих у Свропі, а кількість орної землі, що припадає на одну особу в Україні, перевищує аналогічний показник країн Свропейського Союзу у середньому більш ніж удвічі з половиною [1]. Маючи значний потенціал, Україна його не задіює повною мірою в процесі виробництва, як наслідок, маємо чи не найнижчі показники якості життя серед країн Європи, значну кількість підприємств, що $€$ неконкурентоспроможними на зовнішніх ринках. Питання земельної реформи було визначено у багатьох стратегічних документах держави [2]. Неефективне використання конкурентних переваг країни та природних ресурсів не сприяе повною мірою структурній модернізації економіки та покращенню умов для ведення бізнесу в Україні. Недосконалий механізм реєстрації власності, надмірна ускладненість процедури, витрат часу та коштів, недостатньо високий рівень якості системи управління земельними ресурсами не сприяють повною мірою прозорості системи управління земельними ресурсами, задоволеності користувачів, зростанню рівня сприятливості бізнес-середовища, забезпеченню стійкого зростання економіки екологічно невиснажливим способом.

Аналіз останніх досліджень і публікацій. Тематиці земельних ресурсів присвячені праці багатьох українських та зарубіжних учених. Так, зокрема, антропогенні впливи досліджує Ерл К. Елліс [3], різноманітним управлінським аспектам у сфері земельних ресурсів присвячені роботи Дж. Скотта [4], Р. Росиць- кий досліджує міжнародні та європейські концепції сталого розвитку [5]. Й.Тюнен у праці «Ізольована держава» досліджує поняття земельної ренти, вплив податків на землеробство, податок на земельну ренту. Теоретичні й методичні аспекти управління земельними ресурсами в незалежній Україні досліджували багато вчених, зокрема I.К. Бистряков, А.М. Третяк, які обгрунтували принципи й окремі методи управління земельними ресурсами. Л.Я. Новаковський висвітлював економічні проблеми використання земельних ресурсів. М.Й. Малік досліджує проблеми управління земельними ресурсами аграрного сектору. Р.М. Курильців розглядає інтегроване управління землекористуванням. Проте досвід щодо формування сучасних елементів системи управління земельними ресурсами в Європі не набув достатнього висвітлення.

Формулювання цілей статті. Метою статті є розгляд ролі та значення землі для сталого економічного розвитку на основі аналізу наукових джерел, визначення основних завдань держави у сфері управління земельними ресурсами, вивчення досвіду щодо формування елементів системи управління земельними ресурсами в Європі, розроблення рекомендацій для України.

Виклад основного матеріалу. Аналіз наукових джерел доводить, що землю можна розглядати з різних точок зору: і як ресурс, що не задіяний у процесі виробництва, і як фактор виробництва, що вже використовується в процесі виробництва. Використовуючи інституціональний підхід, що спирається на міждисциплінарний інструментарій, можемо з'ясувати значення 
землі та її роль. Земля є основним ресурсом, оскільки без неї не може підтримуватися життя. 3 фізичної точки зору це $є$ простором, де ми подорожуємо й створюємо житла, звідки ми отримуємо нашу їжу та воду. 3 екологічної точки зору вона відіграє дуже важливу роль у стратегії розмноження та виживання багатьох наявних видів і занадто часто є причиною того, що країна воює з країною, а сусід ворогує із сусідом [7]. 3 юридичної точки зору це $\epsilon$ абстрактною сукупністю майнових прав, а із соціальної та культурної точок зору це $\epsilon$ стрижневим коренем, який живить людей духовною їжею.

З економічної точки зору це $є$ фундаментом, на якому будується добробут. А.М. Третяк розглядає землю у сенсі «землі-матерії», тобто разом із водами, надрами та лісами, оскільки вони є належністю землі, що виникла та існує незалежно від волі та свідомості людини, а також як землю, яка була коморою їжі, арсеналом засобів праці людини, місцем їі поселення. У процесі приєднання до «землі-матерії» праці людини земля стала засобом виробництва, без неї вже немислимий ніякий процес праці, вона перетворилась на «землю-капітал» [8, с. 4]. В сільському господарстві земля є одним 3 основних засобів праці (вона може відігравати також роль базового капіталу), забезпечуючи безперервний процес виробництва продукції як рослинництва, так i тваринництва. Земля може виступати в ролі й предмету, й засобу праці, впливаючи на темпи розвитку та рівень ефективності сільськогосподарського виробництва. Від ефективності використання земельних ресурсів залежить становище багатьох сфер виробництва, зокрема аграрного сектору України, який відіграє значну роль у соціально-економічному розвитку країни. Так, Україна 3 кожним роком нарощує експортний потенціал, зокрема до країн Європейського Союзу.

Отже, земля - це національне багатство, що відіграє роль життєзабезпечення усього населення країни. Земля - це основний ресурс, без якого не може існувати жодна держава світу. Земля є джерелом добробуту. Саме тому дбайливе, раціональне, невиснажливе ставлення до землі має істотне значення для забезпечення сталого економічного розвитку нинішнього й майбутніх поколінь.

Щодо визначення поняття «управління земельними ресурсами», то спочатку варто з'ясувати поняття «управління», яке може використовуватись для характеристики і біологічних, і соціальних, і технологічних систем. Найбільше значення має соціальне управління. Управління в широкому розумінні слова означає цілеспрямований вплив керуючої системи на керовану задля збереження іiї стійкості або переведення з одного стану в інший відповідно до поставленої мети. Процес управління - це впорядкування соціальної системи, через яку буде впорядкована система «земельні ресурси» [9]. Можна погодитися з В.Г. В'юном, що в процесі управління особливе місце посідає причиннонаслідкова залежність, здатна переходити 3 одного стану в інший, оскільки порядкування систем може здійснюватися тільки там, де існує мережа причиннонаслідкових залежностей. Цей процес є прямою протилежністю процесу дезорганізації і, власне, уможливлює стабілізацію системи, забезпечує іï розвиток i досягнення поставленої мети. Функція управління земельними ресурсами притаманна урядам практично всіх країн світу.

В основі ефективного врядування на вищому рівні та ефективної роботи державної адміністрації лежить визнання того, що земля є джерелом добробуту. На думку експертів Європейської економічної комісії ООН, ефективна система управління земельними ресурсами має сприяти землеустрою державних земель, земельній реформі в сільській місцевості, покращувати міське планування й розвиток інфраструктури тощо (рис. 1).

Ефективне управління на вищому рівні, приватна власність на землю та захищеність власності складають основу сталого соціального й економічного розвитку. Без сформованих гарантій захисту прав власності на землю неможливо створити привабливий інвестиційний клімат, залучити внутрішні та зовнішні інвестиції. Щоби цього домогтися, кожна країна повинна мати:

- хороший облік земель, тобто облік прав власності, щоби забезпечити захист власності;

- облік вартості, щоби забезпечити справедливість під час оподаткування землі та нерухомості;

- справедливість під час примусового відчуження землі для досягнення державних цілей;

- облік землекористування, щоби забезпечити ефективне управління ресурсами та стійкість.

Щоби забезпечити раціональне використання земельних ресурсів та сприяти економічному розвитку, держава має формувати відповідне інституційне середовище, систему законів про землю та нерухомість, які визнають права і обов'язки індивіда й загальні інтереси груп населення, що є необхідним, якщо передбачається врахування цих інтересів. Країна не може зберігати стабільність у межах своїх кордонів або підтримувати економічний розвиток, якщо держава не формує та не реалізує земельну політику, яка сприяє зміцненню впевненості у їі громадян і приватних підприємств.

В Україні, відповідно до статті 13 Основного Закону, земля є об'єктом права власності Українського народу. Від імені Українського народу права власника здійснюють органи державної влади та органи місцевого самоврядування. Конституція України визначає, що власність зобов'язує і не повинна використовуватися на шкоду людині й суспільству. Функцією держави є забезпечення захисту прав усіх суб'єктів права власності та господарювання, соціальної спрямованості економіки. Усі суб'єкти права власності, відповідно до Основного Закону, є рівними перед законом. У статті 14 визначено, що земля є основним національним багатством, що перебуває під особливою охороною держави. У Конституції України чітко визначено, що право власності на землю гарантується. Це право 


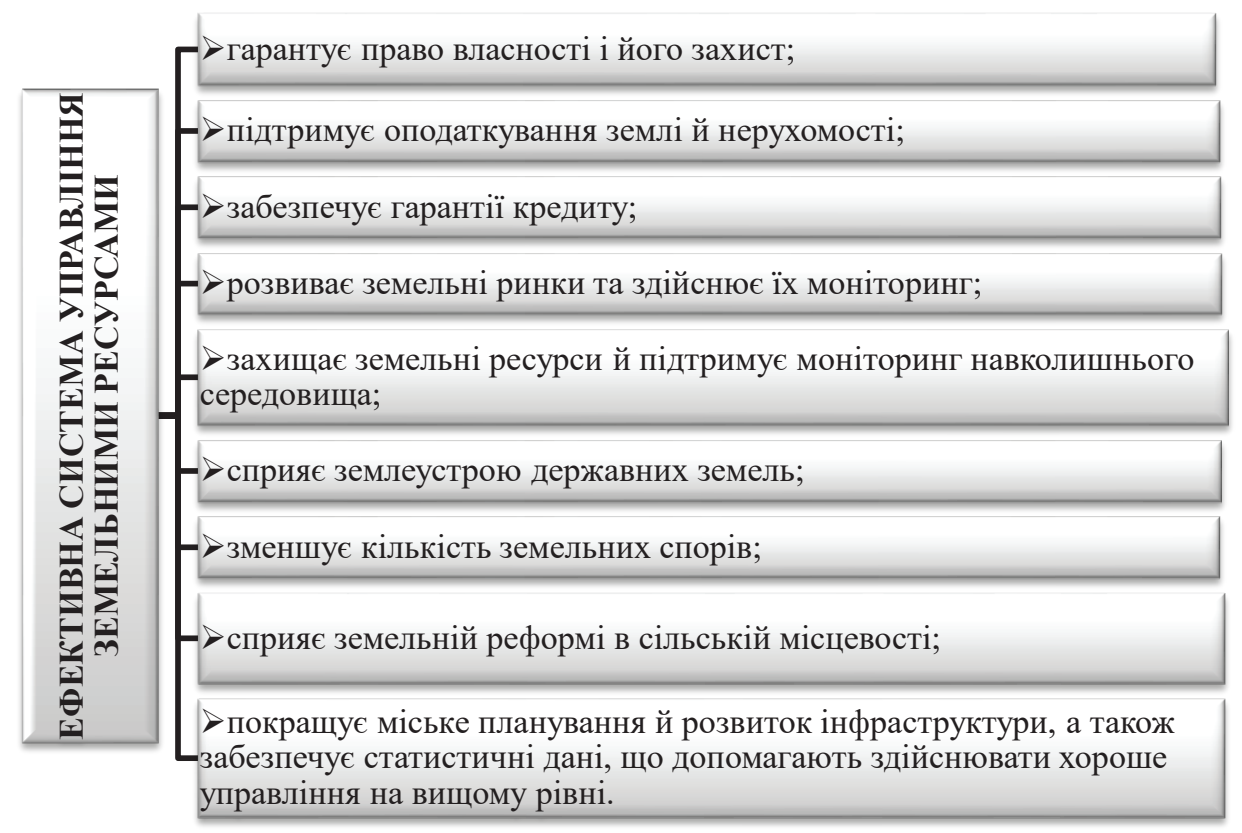

Рис. 1. Ефективна система управління земельними ресурсами

набувається й реалізується громадянами, юридичними особами та державою виключно відповідно до закону. Важливим також $є$ те, що використання власності не може завдавати шкоди правам, свободам та гідності громадян, інтересам суспільства, погіршувати екологічну ситуацію й природні якості землі. Стаття 142 Конституції визначає матеріальною та фінансовою основою місцевого самоврядування рухоме й нерухоме майно, доходи місцевих бюджетів, інші кошти, землю, природні ресурси, що перебувають у власності територіальних громад сіл, селищ, міст, районів у містах, а також об'єкти їхньої спільної власності, що перебувають в управлінні районних та обласних рад [10].

Не менш важливим питанням для України є формування ринку землі сільськогосподарського призначення. Так, уведення у 2001 р. Верховною Радою в Україні мораторію на продаж землі спричинило низку негативних наслідків. Набули поширення тінізація ринку землі, зловживання у сфері земельних відносин, зростання рівня корупції, хабарництво серед чиновників на різних рівнях влади; неефективний розподіл земельної ренти; порушення прав власників на землю; втрата земель запасу та землі резервного фонду, перетворення продуктивних земель на майданчики під забудову тощо [1]. За даними соціологічного опитування у разі винесення питання щодо продовження мораторію на продаж земель сільськогосподарського призначення на Всеукраїнський референдум більшість громадян (77,8\%) проголосувала б за продовження заборони на продаж сільськогосподарської землі. За дозвіл продажу проголосували б 12,6\%. Не брали б участі в референдумі 2,5\%, а 7,1\% не змогли визначитись [11]. Більшість населення в усіх регіонах на Всеукраїнському референдумі стосовно продовження мораторію на продаж земель сільськогосподарського призначення про- голосувала б за продовження заборони на продаж сільськогосподарської землі: у Західному регіоні - 79,1\%, у Центральному - 73,5\%, у Південному - 82\%, у Східному $-77,1 \%$. Фактично однакові частки сільського та міського населення підтримали б на референдумі заборону продажу сільськогосподарських земель, а саме 76,1\% і 78,5\% відповідно. Варто зазначити, що дія мораторію на продаж земель сільськогосподарського призначення була продовжена, як і в попередні роки, на рік, до 2019 р. [12]. У 2020 р. було прийнято Закон «Про внесення змін до деяких законодавчих актів України щодо обігу земель сільськогосподарського призначення» (вводиться ринок землі з 1 липня 2021 р.). Важливими передумовами створення дієвого ринку землі в Україні $є$ проведення інвентаризації земельних ділянок сільськогосподарського призначення усіх форм власності та внесення отриманих за підсумками інвентаризації відомостей про такі земельні ділянки до Державного земельного кадастру, спрощення процедури реєстрації земельних ділянок.

Досвід країн СС доводить, що нові країни-члени ЄС після вступу значно лібералізували ринки землі. Так, більшість нових країн членів СС відкрила ринки для іноземців (переважно для резидентів країн СС). Проте вводився перехідний період (в середньому тривав 7 років) після вступу в СС на володіння землями сільськогосподарського призначення, що дало змогу стабілізувати ринкове ціноутворення. Найбільш жорсткі обмеження щодо землі є в Польщі. Литва, Естонія практично завершили процес лібералізації. Майже в усіх нових країнах ЄС наслідками лібералізації стали зростання цін та значне пришвидшення річного обігу придбання сільськогосподарських земель.

Академік М.Й. Малік, аналізуючи сильні та слабкі сторони системи управління земельними ресурсами 
аграрного сектору економіки України, називає такі пріоритети її вдосконалення, як оптимізація механізму обміну правами землеволодіння, землекористування, відновлення земельних ресурсів між територіальними громадами, державою та зацікавленими особами; залучення інвестицій для формування сталого екологічно зорієнтованого землекористування та відновлення родючості грунтів; створення та функціонування земельного банку; запровадження екологічного страхування (табл. 1).

В Україні комплекс землевпорядних робіт, пов'язаних 3 реформуванням земельних відносин, упродовж 1991-2008 pр. покладався переважно на Інститут землеустрою Української академії аграрних наук. 31998 р. роботи, пов'язані з веденням Державного земельного кадастру, здійснюються Центром Державного земельного кадастру та його дочірніми підприємствами. 32001 р. значний обсяг робіт із землеустрою був перекладений на підприємницькі структури приватної форми власності. Не було розроблено Загальнодержавної програми використання та охорони земель, призупинено роботи 3 прогнозування землекористування, занедбано землевпорядні роботи щодо охорони земельного фонду, підвищення родючості грунтів, консервації земель. Земельно-кадастрові роботи не мають належної прозорості та відкритості, припинено ведення якісного обліку земель за адміністративно-територіальними одиницями [13, с. 16].

В Україні для сучасного стану реєстрації власності характерним $\epsilon$ таке.

1) Надмірна ускладненість процедур. В Україні кількість процедур реєстрації власності дорівнює 7, що є більшим, ніж у таких країнах Свропи, як Грузія (1 процедура), Білорусь (2); країни Свропейського
Союзу, такі як Литва, Естонія, Словаччина (3). За цим показником Україні поступається одна з країн-засновниць Європейського Союзу, а саме Франція, де кількість процедур реєстрації власності дорівнює 8. Такий стан речей щодо кількості процедур в України породжує надмірні витрати часу та коштів.

2) Надмірні витрати часу під час реєстрації власності. В Україні витрати часу на реєстрацію власності становлять 17 днів, що є більшим, ніж у таких країнах Європи, як Грузія, де на реєстрацію власності потрібен 1 день, Білорусь (3), Литва (3,5), де кількість днів не перевищує 3,5. Проте в Україні витрати часу на реєстрацію власності є меншими, ніж у таких країнах СС, як Франція (64 дні), Німеччина (52 дні), а також таких колишніх країнах «соцтабору», що нині є країнамичленами $\mathrm{CC}$, як Словенія (49,5 днів), Хорватія (62), таких країнах-кандидатах на вступ до СС, як Чорногорія (69 днів), Сербія (21) й таких потенційних країнахкандидатах на вступ до $\mathrm{CC}$, як Боснія і Герцеговина (24 дня), Косово (27).

3) Надмірні витрати коштів під час реєстрації власності. В Україні грошові витрати на реєстрацію власності становлять 1,8\% від вартості об'єкта нерухомості, що є більшим, ніж у таких країнах Свропи, як Грузія, Білорусь, Словаччина, де такі витрати відсутні (0\% від вартості об'єкта нерухомості) або ж не перевищують $1 \%$, як у Польщі та Косово (0,3\%), Естонії $(0,5 \%)$, Литві (0,8\%). Проте в Україні грошові витрати на реєстрацію власності $є$ нижчими порівняно з витратами у таких країнах $Є С$, як Франція (7,3\% від вартості об'єкта нерухомості), Німеччина (6,7\%), а також таких колишніх країнах «соцтабору», що $є$ нині країнамичленами СС, як Чеська республіка (4\%), Хорватія (4\%), Угорщина (5\%), таких країнах-кандидатах на вступ до

Таблиця 1

Сучасний стан та перспективи вдосконалення системи управління земельними ресурсами аграрного сектору економіки України [6]

\begin{tabular}{|c|c|c|}
\hline $\begin{array}{c}\text { Сильні сторони } \\
\text { та перспективні можливості }\end{array}$ & Слабкі сторони та можливі загрози & Перспектива \\
\hline $\begin{array}{l}\text { - Запровадження принципів сталого } \\
\text { землекористування; } \\
\text { - використання ринкових інструментів } \\
\text { під час формування; } \\
\text { - активне залучення сучасних } \\
\text { геоінформаційних технологій; } \\
\text { - розроблення еколого-економічно } \\
\text { обгрунтованих проєктів землеустрою; } \\
\text { - завершення інвентаризації та } \\
\text { визначення грошової оцінки окремих } \\
\text { земельних ділянок; } \\
\text { - моніторинг дотримання } \\
\text { землекористувачами земельного } \\
\text { законодавства; } \\
\text { - сприяння іпотечному кредитуванню; } \\
\text { - наявність екологічних норм і } \\
\text { нормативів; } \\
\text { - вжиття природоохоронних заходів. }\end{array}$ & $\begin{array}{l}- \text { Відсутність чіткого планування; } \\
\text { - } \text { недосконалий механізм регулювання } \\
\text { землеволодіння та землекористування; } \\
\text { - } \text { недосконалість механізму } \\
\text { формування та розподілу ресурсних } \\
\text { платежів; } \\
\text { - } \text { невідповідність оцінки } \\
\text { земель їх цінності (особливо } \\
\text { сільськогосподарського призначення); } \\
\text { - відсутність механізму стимулювання } \\
\text { впровадження інноваційної діяльності, } \\
\text { вжиття землеохоронних заходів; } \\
-\quad \text { незавершеність економіко-правового } \\
\text { регулювання земельних відносин; } \\
-\quad \text { недостатній економічний вплив } \\
\text { екологічних стандартів та низька } \\
\text { ефективність управлінських дій; } \\
-\quad \text { порушення екологічно } \\
\text { обгрунтованого співвідношення між } \\
\text { видами угідь, еродованість земель; } \\
-\quad \text { зниження родючості грунтів. }\end{array}$ & $\begin{array}{l}\text { - Оптимізація механізму } \\
\text { обміну правами землеволодіння, } \\
\text { землекористування, відновлення } \\
\text { земельних ресурсів між } \\
\text { територіальними громадами, державою } \\
\text { та зацікавленими особами; } \\
\text { - залучення інвестицій для } \\
\text { формування сталого екологічно } \\
\text { зорієнтованого землекористування та } \\
\text { відновлення родючості грунтів; } \\
\text { - створення та функціонування } \\
\text { земельного банку; } \\
\text { - контроль за вжиттям } \\
\text { грунтозахисних, меліоративних заходів } \\
\text { зі збереженням родючості грунтів; } \\
\text { - запровадження екологічного } \\
\text { страхування; } \\
\text { - залучення громадськості до } \\
\text { процесу забезпечення раціонального й } \\
\text { ефективного використання земель. }\end{array}$ \\
\hline
\end{tabular}


$\epsilon \mathrm{C}$, як Чорногорія (3,2\%), Сербія (28\%). Нижчими $є$ грошові витрати на реєстрацію власності порівняно 3 такою потенційною країною-кандидатом на вступ до $\epsilon \mathrm{C}$, як Боснія і Герцеговина $(5,2 \%)$.

4) Невисокий рівень якості системи управління земельними ресурсами. В Україні індекс якості системи управління земельними ресурсами становить 14,5 , що є нижчим порівняно з індексом якості системи управління земельними ресурсами у таких країнахчленах Європейського Союзу, як Литва (індекс якості системи управління земельними ресурсами становить $28,5)$, Естонія $(27,5)$, Словаччина $(26,5)$, Угорщина (26). Проте за рівнем якості системи управління земельними ресурсами Україні поступається система управління земельними ресурсами в Боснії і Герцеговині (12,5\%).

На думку експертів Світового банку, підвищення позицій у рейтингу “Doing business" на один пункт приводить до зростання обсягу інвестицій на 500 млн. дол. США. Отже, вдосконалення інституційного середовища задля підвищення рівня якості системи управління земельними ресурсами шляхом прийняття низки нормативно-правових актів щодо скорочення трансакційних витрат сприятиме не тільки здійсненню реформ у сфері реєстрації власності, але й залученню інвестицій в Україну.

Варто зазначити, що більшість європейських країн уже автоматизувала свої офіційні земельні інформаційні системи, що дало змогу підвищити рівень якості системи управління земельними ресурсами, що доводять дані міжнародних рейтингів (табл. 2). У зручному форматі обробляється та надсилається в електронну комерцію більш широкий асортимент даних і доку- ментів. На питання про те, як найкраще вести облікові записи про землю на сучасному рівні за високої якості з повним використанням наявних технологій, можна відповісти таким чином: окрім змін організаційної структури, фінансових механізмів і технічних рішень, необхідними є зміни в нормативно-правовій базі, освіті, управлінні тощо.

Для забезпечення якісного управління земельними ресурсами необхідно забезпечити:

- стійкість, що досягається шляхом постійного оновлення устаткування, особливо електронного, модернізації, а цифрові дані повинні постійно оновлюватися;

- захист і конфіденційність персональних даних, що мають бути збалансовані з прагненням до гласності (перевірялася автентичність тих, хто використовує систему, гарантувалася чесність угод і не було ніякої можливості для сторін заперечувати свою участь);

- якість керівництва й рівня тих, хто відповідає за системи, оскільки навіть в електронне століття саме людський фактор визначає, чи є реформи успішними, що потребує значних сил і ресурсів;

- вибір найбільш придатної для країни моделі та системи управління земельними ресурсами, оскільки всі країни, попри їх схожість, $є$ різними.

Система управління земельними ресурсами повинна бути прийнятною за коштами й відкритою для кожного, задовольняючи потреби всіх ії користувачів, а також повинна бути стійкою, тобто постійно оновлюватись та модернізуватись [15].

Варто зазначити, що в країнах Європи набув поширення підхід, орієнтований на комерційну діяльність,

Таблиця 2

Показники ресстрації власності у країнах Свропи [10]

\begin{tabular}{|l|c|c|c|c|c|c|}
\hline \multicolumn{1}{|c|}{ Країна } & $\begin{array}{c}\text { Рейтинг } \\
\text { легкості } \\
\text { ведення } \\
\text { бізнесу }\end{array}$ & $\begin{array}{c}\text { Ресстрація } \\
\text { власності }\end{array}$ & $\begin{array}{c}\text { Процедури } \\
\text { (кількість) }\end{array}$ & Час (дні) & $\begin{array}{c}\text { Індекс якості } \\
\text { Вартість (\% від } \\
\text { вартості об'скта } \\
\text { нерухомості) }\end{array}$ & $\begin{array}{c}\text { системи управління } \\
\text { земельними } \\
\text { ресурсами (0-30) }\end{array}$ \\
\hline Литва & 16 & 3 & 3 & 3,5 & 0,8 & 28,5 \\
\hline Грузія & 9 & 4 & 1 & 1 & 0 & 21,5 \\
\hline Білорусь & 38 & 5 & 2 & 3 & 0 & 23,5 \\
\hline Естонія & 12 & 6 & 3 & 17,5 & 0,5 & 27,5 \\
\hline Словаччина & 39 & 7 & 3 & 16,5 & 0 & 26,5 \\
\hline Латвія & 19 & 22 & 4 & 16,5 & 2 & 22 \\
\hline Угорщина & 48 & 29 & 4 & 17,5 & 5 & 25 \\
\hline Чеська Республіка & 30 & 32 & 4 & 28 & 4 & 20,5 \\
\hline Косово & 40 & 34 & 6 & 27 & 0,3 & 23,5 \\
\hline Словенія & 37 & 36 & 5 & 49,5 & 2 & 19,5 \\
\hline Польща & 27 & 38 & 6 & 33 & 0,3 & 18 \\
\hline Сербія & 43 & 57 & 6 & 21 & 2,8 & 22,5 \\
\hline Хорватія & 51 & 59 & 5 & 62 & 4 & $\mathbf{1 4 , 5}$ \\
\hline Україна & $\mathbf{7 6}$ & $\mathbf{6 4}$ & $\mathbf{7}$ & $\mathbf{1 7}$ & $\mathbf{1 , 8}$ & 17,5 \\
\hline Чорногорія & 42 & 76 & 6 & 69 & 3,2 & 22 \\
\hline Німеччина & 20 & 77 & 6 & 52 & 6,7 & 2,5 \\
\hline Боснія та \\
Герцеговина
\end{tabular}


який гарантує, що процеси управління земельними ресурсами здійснюються економічно ефективно й мають результатом можливості отримувати дохід, який може використовуватися для фінансування робіт, оплати заміни та оновлення технічних засобів.

Загалом до основних фінансових джерел змін земельної інформаційної системи в Європі належать такі:

- оплата інформаційних послуг користувачами;

- довгострокові державні інвестиції в інфраструктуру;

- збори та податки, що стягуються за операції із землею.

У всіх країнах Свропи уряди є головними власниками землі й нерухомості на своїй території. Вони впливають на ринок нерухомості не тільки в ролі регуляторів, але й як учасники ринку. Держава має зменшувати конфлікти інтересів; забезпечувати рівний, відкритий і прозорий доступ до інформації, пов’язаної із землею, для всіх учасників земельного ринку. 3 точки зору прозорості та доступності інформації цікавим $є$ досвід реалізації різноманітних інформаційних проєктів із полегшення доступу до земельних реєстрів, а також функціонування асоціацій у сфері управління земельними ресурсами.

Наприклад, створення Європейської земельної інформаційної служби (EULIS) було підтримано Європейською комісією, Європейською іпотечною федерацією, Свропейською асоціацією реєстрів земельних ділянок, ЄвроГеографік, Європейським бізнес-реєстром. Ініціатива була розпочата з визнання:

- збільшення кількості громадян СС, які купують будинки в інших країнах на вторинному ринку нерухомості;

- того, що індустрія нерухомості стає все більше й більше міжнародною;

- відсутності знань про інформацію щодо землі та нерухомості в інших країнах;

- обмеження іпотечного кредитування національними кордонами тощо.

Miciя EULIS полягала у забезпеченні легкого доступу у всьому світі до європейської інформації про землю та власності для підтримки єдиного європейського ринку нерухомості. Метою було дозволяння клієнту придбати інформацію, що міститься у земельному реєстрі, в будь-якій точці мережі та отримати лише один рахунок від свого дистриб'ютора. Сьогодні не всі країни-члени $Є C$, а лише 21 країна є учасниками цієї ініціативи. Фактично EULIS став першим загальним інформаційним ресурсом про європейську землю та власність у зростаючому числі транскордонних транзакцій, завдяки чому ця інформація може бути миттєвою, інтерактивною та доступною різними мовами, отже, вона може надавати консультації заявнику набагато швидше та якісніше [15]. Проєкт EULIS (2001-2004 рр.) був спрямований на розроблення демонстраційної електронної платформи для підписаних користувачів земельних реєстрів. Одним з фінан- сових джерел цього проєкту виступила Європейська комісія. Програма EULIS (2004-2007 рр.) полягала у сприянні транскордонному кредитуванню інтеграції ринків іпотечного кредитування СС. Офіційно запущена 22 листопада 2006 р. на щорічній конференції EMF (Європейська іпотечна федерація) у Брюсселі. EULIS спочатку перебував у власності консорціуму 3 восьми організацій та регулювався ним, кожна організація якого відповідала за інформацію про землю та майно у своїй власній країні: Англія та Уельс (Земельний реєстр), Ірландія (орган реєстрації об'єктів нерухомості), Литва (Registru Centras), Нідерланди (Kadaster), Швеція (Lantmteriet), Австрія (Bundesministerium fur Justiz), Фінляндія (Maanmittauslaitos), Шотландія (Реєстри Шотландіï). 3 березня 2011 р. EULIS належить Європейській групі економічних інтересів (EEIG) i регулюється нею з представниками різних країн-членів $\mathrm{CC}$, кожна з яких відповідає за інформацію про землю та майно у своїй власній країні.

Свропейська земельна інформаційна служба (EULIS) це:

- онлайновий портал, що забезпечує доступ до земельних реєстрів по всій Свропі, надає доступ до інформації про землю та майно для професійних клієнтів у Європі;

- концентратор інформації про умови реєстрації землі в кожній країні (доступна інформація п'яти держав-членів СС про їхні землі та майно, інші держави-члени $\mathrm{CC}$ на різних етапах працюють у напрямі підключення до служби EULIS), що надає онлайндовідкову інформацію від кожної країни-учасниці, яка детально описує правові рамки реєстрації земельної угоди та іпотечного процесу, наявних послуг, ролі та відповідальності органів влади в процесі земельної угоди, загальну термінологію та інструмент перекладу щоби сприяти розумінню різних правових понять, пов'язаних із земельним правом у СС.

Служба EULIS 2.0 може використовуватися громадянами для деяких простих, безкоштовних запитів, а довідкова інформація надає інформацію про процедури земельного кадастру та кадастрів в інших країнах.

Європейська асоціація земельних реєстрів (ELRA)це одна 3 двох мереж земельних реєстрів, які працюють на європейському рівні, що є некомерційною асоціацією згідно із законами Бельгії, яка складається 3 29 організацій, що представляють земельні реєстри 22 європейських держав-членів. Його головною метою є розвиток та розуміння ролі землі, реєстрація нерухомого майна на ринках капіталу.

Основними видами діяльності Європейської асоціації земельних реєстрів $є$ :

- семінари для обговорення впливу європейських правил на земельні реєстри та їх клієнтів;

- сумісність для земельних кадастрів, які частково фінансуються Свропейською Комісією (IMOLA);

- транскордонне реєстрування в закордонних земельних реєстрах, підтримка іноземних покупців у СC (проєкт CROBECO). 
Висновки. Земля $є$ важливим ресурсом, що має бути задіяний у процес виробництва. «Працюючий» ресурс перетворюється на фактор виробництва, що дає змогу в процесі виробництва створити продукт, який сприятиме задоволенню потреб людини. Перетворення «землі-ресурсу» на «землю - фактор виробництва», задіяння повністю «землі-капіталу» потребують формування відповідного інституційного середовища. Важливу роль щодо управління земельними ресурсами має відігравати держава, яка створює інституційні рамки, формує механізми, інструменти, засоби державного регулювання, що забезпечують прозорість та сталість земельної політики.

Щодо фінансово-кредитних інструментів управління, то досвід країн ЄС доводить, що найбільш результативними є земельні банки, земельна іпотека, пільги 3 кредитування, земельний та екологічний податки, штрафи, оренда, нормативна оцінка землі тощо.

Вивчення зарубіжного досвіду доводить, що для побудови в Україні ефективної системи управління земельними ресурсами необхідно посилити систему гарантій права власності та його захист; удосконалити систему оподаткування землі й нерухомості; забезпечити гарантії кредиту; розвивати земельні ринки та здійснювати їх моніторинг; захищати земельні ресурси й підтримувати моніторинг навколишнього середовища; сприяти землеустрою державних земель; зменшувати кількість земельних спорів; сприяти земельній реформі в сільській місцевості; покращувати міське планування й розвиток інфраструктури, а також забезпечувати статистичні дані, що допомагають здійснювати управління на вищому рівні. Серед фінансово-кредитних інструментів управління важливе місце мають посідати земельні банки, земельна іпотека, пільги
3 кредитування, земельний та екологічний податки, штрафи, оренда, нормативна оцінка землі.

Задля створення ефективної, прозорої, відкритої та гнучкої структури публічної адміністрації із застосуванням новітніх інформаційно-комунікативних технологій (е-урядування), яка здатна виробляти й реалізовувати цілісну державну політику у сфері управління земельними ресурсами, необхідно вдосконалити механізм реєстрації власності. Сьогодні основними недоліками в механізмі реєстрації власності в Україні є надмірна ускладненість процедури реєстрації власності; надмірні витрати часу та коштів під час реєстрації власності; невисокий рівень якості системи управління земельними ресурсами порівняно з країнами $\mathrm{CC.}$

Задля вдосконалення процедури реєстрації власності доцільно:

- спростити процес реєстрації власності шляхом зменшення кількості процедур, що дасть змогу скоротити витрати часу та зменшити грошові витрати;

- поступово зменшити відсоток, що сплачується від вартості об'єкта нерухомості під час його реєстраціï, що дасть змогу зменшити грошові витрати під час реєстрації власності;

- модернізувати наявні та впровадити інноваційні технології подання, оброблення та зберігання інформації, що дасть змогу скоротити витрати часу на реєстрацію власності;

- розмістити у вільному доступі та своєчасно оновлювати інформацію на єдиному інтегрованому веб-сайті щодо переліку суми зборів, необхідних для здійснення реєстрації угод з об'єктами нерухомості, що сприятиме зростанню рівня «прозорості» інформації та підвищенню рівня якості системи управління земельними ресурсами.

\section{Список літератури:}

1. Державне управління регіональним розвитком України / за заг. ред. В.С. Воротіна, Я.А. Жаліла. Київ : НІСД, 2010. 288 c.

2. Про Стратегію сталого розвитку «Україна - 2020» : Указ Президента України від 12 січня 2015 р. № 5/2015/ Президент України. Офіиійний вісник Президента Украӥни. 2015. № 2. С. 14. Ст. 154.

3. Erle C. Ellis Why Is Human Niche Construction Transforming Planet Earth? URL: http://www.jstor.org/stable/26241405 (дата звернення: 19.04.2020).

4. Scot J. Seeing Like a State How Certain Schemes to Improve the Human Condition Have Failed. URL: https://theanarchistlibrary.org/library/james-c-scott-seeing-like-a-state.a4.pdf (дата звернення: 19.04.2020).

5. Rosicki R. Międzynarodowe i europejskie koncepcje zrównoważonego rozwoju. Przegląd Naukowo - Metodyczny. 2010. № 4. P. 44-56. URL: https://repozytorium.amu.edu.pl/bitstream/10593/739/1/Mi\%C4\%99dzynarodowe\%20i\%20 europejskie\%20koncepcje\%20zr\%C3\%B3wnowa\%C5\%BConego\%20rozwoju.pdf (дата звернення: 19.04.2020).

6. Малік М.Й. Управління земельними ресурсами аграрного сектору України: стан та пріоритетні напрями вдосконалення. Актуальні проблеми інноваційної економіки. 2017. № 3. URL: http://dspace.khntusg.com.ua/ bitstream/123456789/1037/1/3.pdf (дата звернення: 19.04.2020).

7. Управління земельними ресурсами в Свропі. Тенденції розвитку та основні принципи. URL: www.unece.org/ fileadmin/DAM/env/documents/2005/wpla/ECE-HBP-140-r.pdf (дата звернення: 19.04.2020).

8. Третяк А.М. Концептуальні засади землеустрою - 2030. Землеустрій, кадастр і моніторинг земель. 2013. № 1-2. C. 4-12.

9. Горлачук В.В., В’юн В.Г., Сохнич А.Я. Управління земельними ресурсами. Миколаїв : МФ НаУКМА, 2002. $316 \mathrm{c}$.

10. Конституція України : Закон України від 28 червня 1996 р. № 254к/96-ВР / Верховна Рада України. Вiдомості Верховної Ради Украӥни. 1996. № 30. Ст. 141. 
11. Результати соціологічного опитування «Українці за продовження мораторію на продаж земель сільськогосподарського призначення (травень 2011 року)». URL: https://polityka.in.ua/info/541.htm (дата звернення: 19.04.2020).

12. Про внесення зміни до розділу $\mathrm{X}$ «Перехідні положення» Земельного кодексу України : Закон України від 7 грудня 2017 р. № 2236-VIII / Верховна Рада України. URL: http://zakon5.rada.gov.ua/laws/show/2236-19/paran2\#n2 (дата звернення: 19.04.2020).

13. Національна доповідь щодо завершення земельної реформи / за наук. ред. Л.Я. Новаковського. Київ : Аграрна наука, 2015. 48 c.

14. Doing Business 2018: Reforming to Create Jobs. URL: http://www.doingbusiness.org (дата звернення: 19.04.2020).

15. About European Land Information Service - EULI. URL: https://joinup.ec.europa.eu/solution/european-landinformation-service-eulis/about (дата звернення: 19.04.2020).

\section{References:}

1. Vorotin V.Y., Zhalilo Y.A. (2010) Derzhavne upravlinnya rehionalnym rozvytkom Ukrayiny [Governmental management of regional development of Ukraine]. Kyiv : NISS (in Ukrainian).

2. Ukaz Prezydenta Ukrayiny (2015) Pro Stratehiyu staloho rozvytku "Ukrayina - 2020" [Decree of the President of Ukraine on the Strategy of Sustainable Development "Ukraine - 2020”]. Official bulletin of the President of Ukraine, no. 2, pp. 154.

3. Ellis E.C. (2016) Why Is Human Niche Construction Transforming Planet Earth? RCC Perspectives, no. 5, pp. 63-70. Available at: http://www.jstor.org/stable/26241405 (accessed: 19 April 2020).

4. Scot J.C. Seeing Like a State How Certain Schemes to Improve the Human Condition Have Failed. Available at: https://theanarchistlibrary.org/library/james-c-scott-seeing-like-a-state.a4.pdf (accessed: 19 April 2020).

5. Rosicki R. (2010) Międzynarodowe i europejskie koncepcje zrównoważonego rozwoju, Przegląd Naukowo Metodyczny, nr. 4, pp. 44-56 (in English).

6. Malik M.Y. Upravlinnya zemel'nymy resursamy ahrarnoho sektoru Ukrayiny: stan ta priorytetni napryamy vdoskonalennya [Land Resources Management of Ukrainian Agrarian Sector: Status and Priority Areas for Improvement]. Available at: http://dspace.khntusg.com.ua/bitstream/123456789/1037/1/3.pdf (accessed: 19 April 2020).

7. Upravlinnya zemel'nymy resursamy v Yevropi. Tendentsiyi rozvytku ta osnovni pryntsypy [Land Management in Europe. Development Trends and Basic Principles]. Available at: www.unece.org/fileadmin/DAM/env/documents/2005/ wpla/ECE-HBP-140-r.pdf (accessed: 19 April 2020).

8. Tretiak A.M. (2013) Conceptual principles of land management - 2030 [Kontseptual'ni pryntsypy zemleustroyu 2030]. Land management, cadaster and land monitoring, no. 1-2, pp. 4-12 (in Ukrainian).

9. Gorlachuk V.V., Vyun V.G., Sohnich A.Ya. (2002) Zemlevporyadkuvannya [Land management]. Mykolaiv : MF NaUKMA. 316 p.

10. Konstytutsiia Ukrainy : Zakon Ukrainy vid 28 chervnia 1996 r. № 254k/96-VR [Constitution of Ukraine: Law of Ukraine of June 28, 1996 № 254k / 96-VR]. Verkhovna Rada Ukrainy. Vidomosti Verkhovnoi Rady Ukrainy. 1996 . № 30. St. 141.

11. Rezultaty sotsiolohichnohoopytuvannia "Ukraintsizaprodovzhenniamoratoriiunaprodazhzemelsilskohospodarskoho pryznachennia (traven 2011 roku)" [Results of a polling poll "Ukrainians for the extension of the moratorium on the sale of agricultural land (May 2011)"]. Available at: https://polityka.in.ua/info/541.htm (accessed: 19 April 2020).

12. Pro vnesennia zminy do rozdilu X "Perekhidni polozhennia" Zemelnoho kodeksu Ukrainy : Zakon Ukrainy vid 7 hrudnia 2017 r. № 2236-VIII [On Amendments to Section X “Transitional Provisions” of the Land Code of Ukraine: Law of Ukraine of December 7, 2017 № 2236-VIII]. Verkhovna Rada Ukrainy. Available at: http://zakon5.rada.gov.ua/laws/ show/2236-19/paran2\#n2 (accessed: 19 April 2020).

13. Novakovsky L. A. (2015) Natsionalna dopovid shchodo zavershennia zemelnoi reformy [National report on the completion of land reform]. Kyiv : Ahrarna nauka. 48 p. (in Ukrainian). 2020).

14. Doing Business 2018: Reforming to Create Jobs. Available at: http:/www.doingbusiness.org (accessed: 19 April

15. About the European Land Information Service - EULI. Available at: https://joinup.ec.europa.eu/solution/europeanland-information-service-eulis/about (accessed: 19 April 2020). 
УПРАВЛЕНИЕ ЗЕМЕЛЬНЫМИ РЕСУРСАМИ: ОПЫТ СТРАН ЕВРОПЕЙСКОГО СОЮЗА

В статье рассмотрены основные аспекты управления земельными ресурсами. На основе анализа научных источников выяснены роль и значение земли для устойчивого экономического развития. Выяснено, что основными недостатками механизма регистрации имущества в Украине являются чрезмерная сложность процедуры регистрации собственности; чрезмерные издержки времени и денег при регистрации собственности; низкое качество системы управления земельныли ресурсами по сравнению со странами ЕС. Определень основные задания государства в сфере управления земельными ресурсами, представлен опыт касательно формирования элементов системы управления земельными ресурсами в Европе и предложены рекомендации. $B$ частности, необходимыми являются усовершенствование механизма регистрации прав собственности, создание эффективной, прозрачной, открытой и гибкой структуры государственного управления с использованием современных информационных и коммуникационных технологий, способных создавать и осуществлять согласованную государственную политику управления земельными ресурсами.

Ключевые слова: земля, управление, Европейский Союз, земельные ресурсы, экономическое развитие.

\section{IMPROVING THE MECHANISM OF THE LAND RESOURCES MANAGEMENT: EXPERIENCE OF THE EUROPEAN UNION COUNTRIES}

The land is an important resource which should to be involved in the production process. The "working" resource is transformed into the factor of production, which allows in the process of production to create a product that will promote the satisfaction of human needs. The transformation of "land-resource" into "land-factor of production", the full involvement of "land-capital" requires the formation of an appropriate institutional environment. An important role in the management of the land resources should be played by the state, which creates an institutional framework, forms mechanisms, tools of state regulation that ensure the transparency and consistency of land policy. With regard to financial and credit management tools, the experience of the EU states that the most effective are: land banks, land mortgages, liens, land and environmental taxes, fines, leases, normative valuations of land, etc. The study of the foreign experience proves that for building a good land management system in Ukraine it is necessary: to strengthen the system of guarantees of property rights and its protection; improve the system of taxation of land and real estate; provide loan guarantees; develop land markets and monitor them; protect land resources and support environmental monitoring; to promote land management of state lands; reduce the number of land disputes; to promote land reform in rural areas; improve urban planning and infrastructure development, and provide statistical data to help ensure good governance at the highest level. Among the financial and credit instruments of management, an important place should be: land banks, land mortgages, lending, land and environmental taxes, fines, leases, normative valuation of land. Today, the main disadvantages in the mechanism of registration of the property in Ukraine are: excessive complexity of the procedure for registration of ownership; Excessive spending time and money when you are registering property; low quality of land management system compared to EU countries. In order to create an efficient, transparent, open and flexible public administration structure with the use of state-of-the-art information and communication technologies (e-government) capable of producing and implementing a coherent state policy in the field of land management, it is necessary to improve the mechanism for registration of ownership.

Key words: land, management, the European Union, land resources, economic development. 